\title{
DE INVLOED DER SPOORWEGEN OP DE REIZIGERS EN BEAMBTEN.
}

Onder dien eenigzins gewijzigden itel $\left(^{*}\right)$ is onlangs een hoogst helangrijk werkje verschenen, warin de inloed der spoorwegen op cle gezondheid van de geërnployeerden en de reizigers die ran dit middel van vervoer gebruik maken, in breede trekken geschetst wordt. Het is de vrucht van een veeljarig onder'zoek, en bevat zoowel de uitkomsten van de nasporingen des schrijuers $(\dagger)$ als van die van andere schrijvers, meestal de geneesheeren aau de groute spoorwey-liniën van Frankrijk, op dat gebied opgedaan. De schrijver heeft aan zijne hyg̣ènische beschouwingen relc bijzonderheden vas cconomisch-alministratieven aard geknoopt, en in verbaud darmede is het ons - bij de op banden zijude uilbreiding van het spoorweg-stelsel in Nederland - van genorgzam belang voorgekomen, den lezers van dit Tijdschrift wet den hoofd-inhoud vau dat geschrift bekend te maken.

De schrijver heeft zich in zijn arbeid voorgesteld, de drie volgende stellingen te bewijzen:

$1^{0}$ De spoorwegen oefenen, behoudens enkele uitzonderingen, een gunstigen invloed uit op de openbare gezondheid;

$2^{0}$ De ongelukken, van welken and ook, zijn veel geringer bij de reizigers op de spoorwegen, dan op elk ander middel van vervoer;

$3^{0}$ Hun invloed op al de geemployeerden is zeer gunstig.

Alvorens tot de eigenlijke taak over te gaan, heeft de Schrijver het noodig geoordeeld, zijne lezers tot het gewigtige onderwerp in te leiden door enige algemeeue beschouwingen te leveren over de rol die de gezondheidsleer in het sociale leven speelt, welken invloed zij op de beschaving, in het afwenden en voorkomen van matschippelijke ge-

(*) Chemins de fer et santé publique, hygiène des voyageurs et des employés; par le Dr. Prosper de Pietra Santa. Paris, Hachelte, 1861.

(†) In de Anuates d'hygiène publique et de médecine légale, 2de série, 1859, heeft de Sulmijver reeds ene nitvoerige studie over den invloed der spoorwegen op de openbare gezondheid geleverd, waraan de onderwerpelijke thans gruotolijks ontleend is. 
breken en onheilen uitoefent. Wij kunnen deze beschouwingen hier gerust voorbijgaan, omdat wij ze niet strikt tot ons doel noodig hebben, te minder daar zij slechts de uitkomsten leveren die de toepassing van de hygiène in Frankrijk heeft opgeleverd. Voor deze bijzonderbeden verwijzen wij den belangstellenden lezer naar het werkje zelf.

In de eerste plaats dan stelt de Schrijver, op gezag van de fransche commissie van enquête naar den toestand der spoorwegen, de volgende vereischten die men bij de exploitatie van spoorwegen heeft in acht te nemen:

$1^{0}$ Eene goede keus van het personeel in alle takken van de dienst;

$2^{0}$ Eiene volkomenheid van het stelsel van vervoer en alle toestellen die op den weg zijn geplaatst om de goede rigting en gang der treinen te verzekeren;

$3^{0}$ Len goed, eenroudig en beknopt reglement voor de exploitatie, zoodanig ingerigt, dat de beambten het gemakkelijk begrijpen en onthouden kunnen.

Deze drie hoofdpunten worden vervolgens nader uiteengezet. Wij zonden te uitvoerig worden, wilden wij den schrijver hier op den voet volgen, Wij zullen volstaan met enkele belangrijke weuken aan te stippen. Tot eene goede directie wordt vereischt: $a$. eene verstandige keuze van bet personeel, zoowel wat betreft de zedelijkheid als bekwaamherd, $b$. een voldoend aantal beambten in verhouding tot den omvang van de dienst, $c$. eene gelijkmatige verdeeling van den duur des arbeids, $d$. eene voldoende belooning voor de gevorderde diensten.

Voor de dienst bij de fransche spoorwegen worden gewoonlijk gepasporteerde militairen gekozen; zij maken op de ouderscheidene takken van $34-67 \mathrm{pCt}$. van het personeel der be:mbten uit.

In 1854 was de verhouding van het personeel tot de geexploiteerde spoorweglengte op de ooster-en milden-spoorwegen 7 per kilometer. In Engeland bedragt het 7,, in Pruissen 7,2 p. kilom. Die verhouding is voldoende, om niet te veel van de physirke krachten van het personeel te eischen. Het spreekt van zelf, dat de arbeidsduur voor elke klasse van beaubten verschilt. De vermoeijenis of duur van den arbeid strekt tot grondslag van dien maatstaf.

Onder de kwestiëu die voor de openbare gezondheid en veiligheid en die der beambten van het meeste belang zijn, behoort de regeling van den arbeidsduur der stokers en machinisten. Blootgesteld toch als ze ziju aan alle temperatunrs-reranderingen, gedwongen om altijd te staan, bij een aanhoudenden arbeid, afgewisseld door weinig slap of rust, kan 
een onvoldoend toezigt allernoodlottigste gevolgen na zich slepen. Lat ons de oplossing van dit vraigstuk in de nasporingen van den Schrijver voor de fransche spoorwegen eens trachten na te gaan.

De grootste afstand door een stoker dagelijks afgelegd, is:

$$
\begin{array}{ll}
\text { op den noorder-spoorweg } & 460 \text { kilom. } \\
\text { " ", spoorweg van Orleans } 470 " \\
\text { "dien van Roman } & 456 "
\end{array}
$$

Op de lijo van Parijs naar Lyon is de gemiddelde diensttijd:

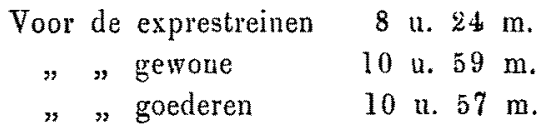

Die diensttijd schijnt noch te lang, noch te vermoeijend.

Het gemiddeld der ruimte gedurende eene maand doorloopen was:

Voor de machinisten der passagierstreinen 3200 à 3400 kilom.

Voor de maclínisten der goederen-treinen 3400 à 3600 "

Op de lijn van Orleans maandelijks gemiddeld 3360 kilom.

De langste togten door de machinisten gemaakt, waren die:

Vsn Tours naar Angoulême (heen en terug) 428 kilom.

Van Parijs naar Tours

470 ”

Deze ritten worden door een afwisselend personeel bediend, zoodat ze nimmer dagelijks door één persoon worden afguelegd, en in dat geval de dienst slechts $8-9.20 \mathrm{u}$. bedraagt, terwijl de gemiddelde dagdienst der andere machinisten die de tusschen-afstanden van den weg afleggen, $8-10 \mathrm{u}$. voor de passagiers-treinen en $6-8$ u. voor de goederen-treineu bedrangt. Bij de gemiddelde dagelijksche dienst wordt door de machinisteu ten hoogste 4.72 en gemiddeld 117 kilom. afgelegd, voor de goederen-treinen 242 , gemiddeld $107 \mathrm{k}$.

De werktijd, die bij een voldoend personeel door behoorlijke tijden van rust wordt afgewisseld, heeft alzoo niets bezwarend voor die soort van beambten.

Al het opgesomde betrefiende de dienst der machinisten geldt ook voor de stokers.

De vermoeijenis die bij deze benmbten door de dienst ontstant, moet niet naar de grootere of kleinere afstanden die afyelegd worden, manr wel naar het langer of korter verblijf op de locomotieven gerekend worden. Zoo is bijv. de exprestrein van Tours naar Parijs, waarbij 200 kilom. in de 24 uren worden afgelegd $\left({ }^{*}\right)$, minder vermoeijend

() Men verwarre deze cijfers niet met die rau de snelheid der treinen. De expres-treinen rijden doorgaans 1 kilometer per minuut; hier schijut bedoeld de afstand door elk machinist doorloopen.

RED, 
dau de goederen-trein van Orleans, ofschoon daarbij in dienzelfden tijd slechts 100 kilom. worden afgelegd.

In verband met deze gewigtige diensten is de verzorging en belooning der beambten op de fransche spoorwegen zeer voldoende. Ten einde in eene goedkoope levenswijze te gemoet te komen, hebben de spoorwegdirectiën van de lijnen van Orleans en du Micli, depôts van levensmiddelen oprerigt, waaruit zich al de beambten van goedkoope en deugdelijke levensbehoeften kunnen voorzien. De Compagnie du Midi heeft daaran ook gaarkeukeus en kleĉren-magazijnen toegevoegd.

De stokers en machinisten worden boven humne gewone bezoldiging voor extra-diensten betaald, terwijl zij nog 10 kilogr. brandstofien erlangen en $\frac{1}{3}$ van de bespaarde brandstoffen op elken afgelegden togt. Voorts zijn onder de geëmployeerden onderstands- en zieken-vereenigingen opgerigt, waaruit zij in ziekten en bij gebreken en ouderdom ondersteund worden; elke beambte zondert daartoe van zijn loon een zeker deel af. De compagnie stort bovendien mandelijks eene zekere som van de winsten in de onderstandskas.

De bijzonderheden die de schrijver vervolgens mededeelt omtrent de maatregelen, welke op de fransche spoorweyen zijn ingevoerd tot eene geregelde en veilige dienst, moeten $w i j$ hier, weder uit vrees van te groote uitvoerigheid, stilzwijgend voorbijgaan, te meer daar wij er later nog op terug moeten komen.

Vervolgens overgaande om den invloed te schetsen dien de spoorwegen op de gezondheid der reizigers hebben, stelt de schrijver zich de beantwoording der drie volgende vrigen voor:

A. Welke zijn de algemeene voordeelen waardoor zich de spoorwegen, bij den tegenwoordigen toestand der maalschappij, onderscheiden?

B. Welke zijn de uitkounsten door directe waarneming verkregen om. trent hunuen invloed op de gezondheid der reizigers?

C. Welke zijn de bewijsgronden die, op eene reeks van andere feiten steunende, de eerstgenoemde uitkomsten bevestigen?

Wij moeten bekennen dat wij ons bij de lektuur vau deze $\$$ jammerlijk in onze verwachtingen vonden teleurgesteld.

Uit zijne redeneringen en bewijsgronden blijkt maar al te duidelijk, dat de Schrijver zich mei de oplossing dier rraagstukken verlegen heeft gevondeu. Hij tracht er zich dan ook met "een franschen slag" door heen te redden. Hetgeen bij ons meêdeelt vau de zedeijke en physieke voordeeleu, van de besparing van tijd en geld, van de meerdere verspreiding der volken, van de voorregten dat men thans meer van de vrije lucht op het land eu aan de zee kan gerieten, dat men meer nabij zijne vrienden en zicke betrekkingen is, dat ecne moeder haar 
kind gemakkelijker naar de badplaatsen kan volgen, dat de mindere standen hunne Zon- en rustlagen nu meer in het genot van de vrije Iucht kunnen doorbrengen, terwijl hun geest en gemoed, door de voortbrengselen van natnur en kunst die zij op hunne uitstapjes leeren kennen, hierdoor meer veredeld worden, is reeds tot vervelens toe herhaald; evenzoo hebben de pessimisten en behoudsmannen eene lange serie van ziekten en kwalen aangegeven, welke door het verkeer op de spoorwegen bij de menschheid zou warrgenomen zijn, doch die gelukkig bij eene onbevooroordeelde beschouring, bleken uit de lucht gegrepen te zijn. De Schrijver hecht teregt aan deze laatste beweringen geene waarde.

Wat den onmiddellijken invloed van het spoorwegen-vervoer op de reizigers betreft, ook hier is de oogst maar schranl, en noch die reeks van hartkwalen of beroerten en allerlei zenuwaandoeningen of ontstekingen door het aanhoudend schokken, of den sterken luchtstroom, of eindelijk de gedurige angst, waarin de reizigers verkeeren, welke men als gevolgen van het grooter verkecr op de spoorwegen heeft opgegeven, hebben zich bevestigd; integendeel, de Schrijver houdt het er voor, dat het verkeer op en door de spoorwegen een allerheilzaamsten invloed op de reizigers in bet bijzonder en de maatschappij in het algemeen uitoefent.

Het spreekt van zelf, dat het nogtans moeijelijk is om al deze beweringen door juiste feiten op eene groote schaal te staven, en daarom mag men er niet meer warde anu hechten dan aan het aangevoerde over zoo vele andere middelen die op het gebied der maatschappelijke beschaving in het leven zijn geroepen. Zij zijn alleen de voertuigen die hun invloed slechts middellijk, zoowel ten gunste als ten ongunste, doen gelden.

Meer heeft ons de Schrijuer daarentegen bevredigd, als hij bewijzen gaat leveren van de voordeelen die dit middel van vervoer aanbiedt aan de reizigers in betrekking tot hunne veiligheid. Daartoe treedt bij in uitvoerige becijferingen en vergelijkingen met de ongelukken door andere midldelen van vervoer te weeggebragt.

Wij zullen eenige uitkomsten van die becijferingen mededeelen.

Van deu 7 Sept. 1835 tot den 31 Dec. 1856, bedroeg het antal passagiers vervoerd langs al de lijnen der fransche spoorwegen 224.345.769.

Het anntal ongelukken van allerlei aard bedroeg 2978 ; daarvan waren 1134 gevallen door onachtzanmheid of verznim bij de spoorweg-directie en 1844 door onvoorzigtigheid der reizigers te weeg gebragt. 160 reizigers waren gedood, dus 1 op 1.402.161; er waren 509 gekwetst, dus I op 440.759 , hetgeen een totaal van 669 slagtoffer's uitmaakt, alzoo $I$ op 
335.491 (daaronder nemen eene groote plats in de 2 ongevallen, die op de linker-en noorder-takken, bij Versailles en Fampoux hebben plaats gehad, welke ann 64 reizigers het leven kostten).

Wanneer wij daarmede vergelijken het aantal ongelukken dat door gewone rijtuigen plaats grijpt, dan zal het voordeel ter gunste der spoorwegen eerst regt uitkomen.

B. v. Van 1840 tot 1853 zijn door rijtuigen, karren en parden 10324 personen gedood of gekwetst, en de bevolking van Frankrijk op 3a mill. zielen stelleude, kan men gemilldeld jaarlijks op 737 ongelukken door die vervormidlelen te weeg gebragt, rekenen, of 1 op 47.489 .

In 1859 waren door dezelffle soort van vervoermidrielen 1161 personen gelood of gekwetst, hetgeen volgens het eijfer der berolking, eán ongreluk op 31.144 personen uitmakkt.

Door de keizerlijke en particuliere postwagen-ondernemingen waren van 1846 tot 1855 pervoerd 7.109 .276 reizigers, waarbij 20 omkwamen en 238 gekwetst werden, alzoo:

$\begin{array}{llrc}1 \text { doode } & \text { op } & 355.463 & \text { reizigers } \\ 1 \text { gekwetste } & " & 29.871 & " \\ 1 \text { slagtoffer } & " & 27.551 & "\end{array}$

Van 1856 tot 1860 heeft de keizerlijke postwagen-onderneming (waaronder zich mu ook de rroegere particuliere ondernemingen bevinden) eene ruimte van $26.4: 28.581$ kilometers afgelegd en diarbij 1.868 .174 reizigers vervoerd; op dit antal kwamen 4 dooden en 62 gekwetsten alzoo I ongeluk op 28.305 personen.

Wanneer men nu de verhourding van het antal ongelukken op de spoorwegen met die van de gewone postwagens vergelijkt, dan krijgt men de volgende uitkomst:

Op de spoorwegen 1 ongeluk op 335491

Met de andere verroermiddelen 1 , \# 27.555

of $13: 1$, met andere woorden, men heeft 13 maal meer kans om eene goede reis te volbrengen wanneer men per spoor, dan wanneer men per diligence reist.

Naast zijne eigene nasporingen stelt de Schrijver ook de nitkomsten in andere landen, bij het gebruik der spoorwegen verkregen.

De statistiek der belgische spoorwegen van 1 Mei 1835 tot 31 Dec. 1848 toont aan, dat op 35.447 .217 reizigers, 295 ongelukken voorkwamen (daaronder zijn begrepen 48 personen die gedood of gekwetst werden doordien ze op den reg liepen, en 12 zelfmoorden). Op de 235 overhlijiendeu zijn 17 ongekomen en 58 gekwetst door schuld der spoorwegdirectie; 57 dooden en 103 gekwetsten hadden aan eigen schuld hun ongeluk te wijten. In slotsom komen slechts 4 sterfgevallen en 
18 kwetsingen op rekening van de directie. [De onlangs openbaar gemaakte statistiek van het aantal ongelukken op de belgische spoorwegen levert, sedert de opening der lijnen tot 1861, slechts 6 dooden en 74 gewonden door omstandigheden in de dienst veroorzankt. Ref] Vergelijkt men deze cijfers met de doorloopen ruimte en het aantal vervoerde reizigers in dit 13 jarig tijdvak, dan verkriiggt men:
1 doode op 8.861 .804 reizigers; en
1 gekwetste op bijna 2 millioen; of
1 slagtoffer op 1.611 .237 reizigers.

In Pruissen werden van 1851 tot 1854 vervoerd 42.822 .976 reizi. gers, in welk tijdvak 220 personen geduod en 327 gekwetst werden. De ongelnkken aan de exploitatie te wijten, bedroegen slecbts 41 , waarvan 2 reizigers gedood en 11 gekwetst werden, hetgeen alzoo geeft:

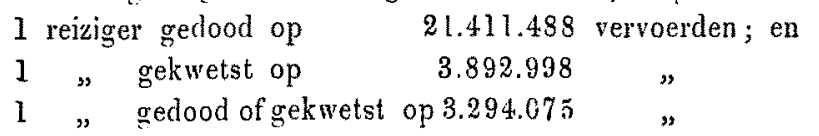

In Groot-Brittannie waren van 1840 tot 1856 vervoerd 940.876 .386 reizigers, waaronder 2735 geclood en 4371 gekwetst werden, terwijl op rekening der exploitatie 179 dooden en 2843 gekwetsten of in het geheel 3022 slagtoffers kwamen. De verhouding der ongelukken was aldaar:

$\begin{array}{llrcc}1 \text { doode op } & 5.256 .290 & \text { vervoerde reizigers; } \\ 1 \text { gekwetste } & 330.945 & & \\ \text { J doode of gekw. " } & 311345 & & \end{array}$

Op de spoorwegen in de Vereenigde Staten werd in 1855 : gedood 1 reiziger op 286.179 verv, reizigers. gekwetst l " $\Rightarrow 90.739 "$ "

Wanneer men deze cijfers der spoorweg-ongelukken onderling verze. lijkt, dan zal men nog al in het oog loopende verschillen ontwaren. Zij ontstaan deels door onvoldoende zorg der administratie voor de middelen van vervoer (wegen, rijtuịen, machineriën en beambten), deels door de grootere snelheid, die an de treinen gegeven wordt.

In Frankrijk is de snelheid (expres) op den noordertak 70 à 75 kilom. per uur, in België 50 à 60 kilom. op de treinen in correspondentie met Frankrijk, 40 aे 45 op de andere takken en 30 kilom. gemiddeld voor alle treinen. In Duitschland gaat die snelheid 40 à $4 \check{o}$ kilom. per uur niet te boven.

Wanueer men ten slotte het aantal spoorweg-ongelukken vergelijkt met dat door gewone rijtuigen veroorzakt, dau zal de schal wel altijd ten gunste der eerste moeten overhellen, en de uitspraak van PaouiN wordt hier dus bevestigd: „Si l'on va vite, ce n'est pas vers la mort que l'on court." 
Eren onbevredigend als de schrijver ons gelaten heeft bij de uiteenzetting van "den invloed der spoorwegen op de gezondheid der reizigers," zoo onvoldaan bleven wij bij de lectnur van de $\$$ die handelt „over de hygiène der reizigers" Behalve enkele wetenswaardige bijzonderheden die wij daar vernemen ten opzigte van de inrigting der fransche spoorwegen in het helang van de gezondheid en veiligheid der reizigers, en eenige behartigingswaardige, doch algemeen bekende - niet altijd ter harte genomene - wenken voor het verkeer op de spoorwegen, vonden wij daarin niets wat ons zon nopen hierover breedvoerig nit te weiden. Bnkele punten willen wij, als ter loops, evenwel aanstippen.

Elke trein is voorzien van een verbandkıst, waarin geneesmiddelen en instrumenten aanwezig ziju, om bij een onverhoopt ongeval, terstond de eerste hulp te kunnen verstrekken.

Ten einde de stokers en machinisten ten allen tijde de trein in het gezigt zullen hebben, heeft men aan den tender eeu spiegel aangebragt. Men kan zoodoende het minste signaal, dat de conducteurs of de reizigers bij onraad geven, waarnemen, en de trein wordt gestopt; 's avonds worden die spiegels door lampen verlicht, maar dan doen ze evenwel minler nut. In verband daarmede bee $e^{f}$ men aan le beambten betere gelegenheid verschaft om de rondes te kunnen maken door ruime gangboorden langs de wagens.

$\mathrm{Om}$ de veiligheid te verzekeren is de invoering van het système Bonelli (telegraafdraden die de wagens met de telegraaflijnen langs den weg in verbinding stellen) beproefd. El zijn eenvoudige koorden langs de wagens gespannen, die eene onmiddellijke gemeenschap tusschen de machinisten en de opzigters van den trein daarstellen.

Ten opzigte der verlichting vermellt de schrijuer de proeven die genomen zijn om de wagens met zamengeperst gas te verlichten. De communicatie met het reservoir en de wagens onderling geschiedt door buizen van cnoutchonc. Dit stelsel, in Amerika in zwang, is op de fransche spoorwegen nog slechts als proeve aangerend. De gasondernemer Hugns heeft die verlichting tevens als een model van verwarming voorgesteld, zonder dat het echter toepassing heeft gevonden. Onder de andere middelen van verwarming heeft men ook de wagens van ijzeren bollen roorzien, gevuld met heet water. Dit middel kon alleen in de wagens der lste kl. met vrucht gebezigd worden. $\ln 1858$ heeft een ingenieur een ander stelsel uitgedacht, op al de wagens van toepassing. Hij verbindt namelijk de stoomkran van den locomotief met eene koperen buis van 2 à 3 centim. doorsnede. Door midllel van caoutchouc buizen wordt de stoom in jjzeren buizen geleid, die langs 
de zijde der wagens zijn aangebragt. De spoorweg-administratie van Lyon heeft op hare lijn daarmede eene proef genomen, en dagbladen hebben verkondigd dat deze proeve met den besten uitslag is bekroond. Trenwel zijn daartegen onderscheidene bezwaren -ingebragt, waaronder dat van de ongelijkmatige verwarming der wagens wel het gewigtigste is. De schrijver gelooft dan ook, op gezag van de commissie an welke eene enquête dier zaak was opgedragen, dat het oude stelsel van door heet water verwarmde bollen, meer nut en minder schadelijke gevolgen zal aanbrengen dan de nieuwe methode (*).

Bij elke invoering van verwarning-toestellen op de spoorwegen wordt het overigens nog meer noodzakelijk voor eene goede ventilatie te zorgen, daar de lucht spoediger zal bedorven worden bij een verblijf van eenige uren door een zeker aantal personen in eeue beperkte ruimte die bovendien kunstmatjg verwarmd is. De temperatuurwisselingen zullen bij het openen vau deuren en ramen en bij het verlaten der wagens daar nog grooter en schadelijker zijn dan waar men niet van verwarmde wagens gebruik maakt. Het stelsel van ventilatie behoort alzoo ook verbeterd te wordeu, waarmede men op onderscheiden lijnen der fransche spoorwegen zeer vindingrijke proeven heeft genomen, welke aan de vereischten voldeden.

Voorts zijn ter dienste van zeer zenuwachtige en zwakke personen, zwangere vrouwen, zieken en berstellenden, op sommige lijnen ingevoerd coupés-lits, waarin de lijlers in elke houding kunuen plaats nemen, zonder dat zij, zelfs bij hevige botsingen der wagens of stootende wegen, den minsten schok oudervinden. De zorg van sommige administratiën is zelfs zoo ver geyaan, dat men coupés heeft ingerigt poor lijders anu contagieuse ziekten, zoodanig dat reizigers die zelfs op reis bet contagium willen ontvlugten, veilig daar plaats kunnen nemen, zonder vrees dat zij zich eene afzigtelijke huidziekte of een gevreesden typhus zullen op den hals halen.

$\left.{ }^{*}\right)$ Elet verwarmen der wagens des winters en het koelhouden des zomers is een aanhoudend onderwerp van zorg voor spoorwegdirectiën. Het laatste is echter vrij wat moeijelijker dau het eerste. Men kan veeleer 's winters goed warm zitten dan dat men des zomers een koelen spoorwagen aantreft. Het middel, naar wij meenen reeds hier en daar toegepast, om de wagens een dubbele bedekking te geven met de noodige luchtruimte daartusschen, rerdient, waar het niet te kostbaar is, in anmerking te komen.

Ook het glimmend wit verwen der wagens, althans het bovenvlak, is weleens door deskundigen aungernden. Er zijo die beweren dat dergelijk wit glinstcrend vlak 15 pCt meer warmte terugkaatst dan een zwart of donker geverwd vlak.

RED، 
Welk een goeden dunk wij ook, bij onze annstande staatsspoorwegen $\left(^{*}\right)$, van ouze regering koesteren, wij gelooven niet, dat zij de zorg voor hare trekkende kinderen zoo ver zal uitstrekken. Wie kan echter in onzen tijd van vooruitgang en philanthropie met zekerbeid bepalen, dat we ook ten onzent niet nog eens van die stoomende hospitalen zullen zien? Het krijgshaftige Frankrijk heeft hier weder op een aanstaandeu oorlog gespeculeerd en de spoorwegadministratiën zijn er op uit, om bij de eerste aanvrage, eene kolossale ambulance op hare lijnen gereed te hebben. Als de woeste hoop dan maar niet de spoorstaven opbreekt!

Waar de schrijver het artikel "kleeding op de spoorwegen " behandelt, is de onde lens: "hond de voeten warm en het hoofd koel" ook de zijne. 's Zomers linnen kleêren, 's winters goed gevoerde overjassen en laarzen. Jammer maar, dat de reizigers 3de $\mathrm{kl}$, die toch wel het meest aan koû en togt zijn blootgesteld, zịnen raad niet strikt kunnen volgen, tenzij de zorgzame fransche spoorwegadministratie kon besluiten, langs de verwarmile pijpen viltpantoffels te plaatsen - (maar dan aan de pijpen vastgelsecht, anders zou welligt de een of andere haastige reiziger kunnen vergeten zijn schoeisel uit te trekken).

Den rad om op de lange toutjes de treinen bij de halten van tijd tot tijd te verlaten en dan eenige mal $n$ op en neêr te wandelen, of in de restauratie een warm kop chocolaad of wat grog te gann gebruiken, zal niemand hem euvel duiden. Hij beveelt echter voorzig'igheid aan in het te spoedig en te overmatig gebruik van spijzen endranken (vooral van sterke dranken) op de spoorwegen. Het korte verblijf op de halten en de lange trajecten leiden er soms toe, om binnen den kortstmogelijken tijd ongelijk groote massa's spijzen te verzwelgen. Wij gelooven echter dat de restaurateurs op de spoorweglijnen wel zullen zorgen. dat noch de maag noch de beurs der reizigers te sterk aan overlading lijden.

Op voorstel wan Vernats raadt de schrijver ten slotte de spoorwegdirectien aan, om $1^{0}$ uimmer de reizigers in de wagens op te sluiten; $2^{0}$ nimmer versch geverwde wagens in grebruik te nemen; $3^{0}$ elkepassagierstrein door een of twee wagens, gevuld met zakken met zand, in te sluiten ; $4^{0}$ de goederen- en veewagens te desinfecteren, en $5^{0}$ nim-

(3) Trouweos, dergelijke raffinementen, boe nuttig ook in vele gevallen, zijn louter kwestien van exploitatie, en bij ons is tot heden nog geenzins uitgemakt, zelfs niet warsohijnlijk, dat een stelsel van een staats-exploitatie der spoorwegen zal ingevoerd worden.

RED. 
mer gelijktijdig met passagierstreinen ontbrandbare en ontplofbare stoffen te vervoeren. (*)

In de $\$$ die handelt "over den invloed der spoorwegen op de gezondheid der beambten", is de schrijver weder geheel op zijne plaats en geeft hij zijnen lezers meer dan woorden. De irrigting van de geneeskundige dienst op de fransche spoorwegen maakt eene jniste beoordeeling van dien tak van industrie op het personeel in alle opzigten gemakkelijk. Dit veld van onderzoek is daarom in de lantste jaren door de voornaamste geleerlen die Frankrijk oplevert, vlijtig bearbeid, en de onwraakbare getnigenissen der eijfers hebben sommigen van menige dwaling teruggebragt en menige zaak, door eenzijlige - beschouwing verkeerd beoordeeld, thans in een helder licht gesteld en den waren toestand aan den dag gebragt. Onder de mannen die dit onderwerp regt grondig en onbevooroordeeld bestudeerd hebben, behoort de schrijver van het door ons besproken werk. De onpartijdige behandeling van het hoofdstuk, dat wij thans te beschouwen hebben. doet ons de viijheid nemen, zijne uitspraken als die van eene autoriteit hier over te nemen.

De inriging van de geneeskundige dienst op de spoorwegen ten opzigte der heambten, berust op de volgende grondslagen: $1^{0}$ om bij ongelukken terstond de eersie hulp te verleenen; 20 aan de zieken en herstellenden geneeskundige hulp te verschaften; en $3^{0}$ om de gezondheid van allen, door bet in acht nemen van de voorschriften der bygiène, te verzekeren.

Een corps geneeskundigen is tot dat einde aangesteld, waarvan elk een zeker antal beambten, in den kring van 20 à 40 kilom., in geval van nood verplegen, en geregeld anteekening moet houden van den gezondheidstoestand van het personeel, waarover bij, in driemaandelijksche en jaarlijksche rapporten, aan de hoofdadministratie verslag moet geven. Deze verslagen leveren de bouwsloffen ter beoordeeling van den invloed der spoorwegen op de gezondheid, en onze schrijver heeft voor zijue beschouwingen inzonderheid van deze documenten gebruik gemaakt. Zij omvatten de lijuen van Lyon, Orleans, de Noorder- en Oosterspoorwegen. Als slotsnm van de vergelijkende statistieken door den schrijver geleverd, ontwaren wij dat, terwijl de gemiddelde jaarlijksche sterfte

$\left(^{*}\right)$ Vele voorschriften van dergelijken aard kunnen thans ook eerlang bij onze spoorwegen, ook bij de reeds bestaande, te gemoet worden gezien. Art. 24 der spoorweg-politiewet bepaalt ul. dat een alg, matregel van inw. bestuur de noodige voorschriften zal geven ontrent veiligheid en orde op den weg, de treinen euz. Die maatregel zal, naar men vermeent, weldra tot stand zijn gekomen. RuD. 
voor de bevolking van Parijs tusschen de 20 en 25 jaren oud (van 1855-1859) bedroeg $1.99 \mathrm{pCt}$, - voor $18592.08 \mathrm{pCt}$ - - de sterfte voor het personeel van den spoorweg van Orleans slechts $0,6 \mathrm{pCt}$. (over een personeel van 12494 beambten) bedroeg,

Op den spoorweg van Lyon was de verhouding van de zieken tot de gezonden als 6 à $10: 100$. Ieder van de 13588 beambten en werklieden is gemiddeld $1 \frac{1}{8}$ maand, gedurende de 54 maanden wanrover het onderzoek liep, ziek geweest. De sterfteverhouding was 1 op 115 , waaronder de beambten van de active dienst slechts voor $\frac{1}{8}$ deelden.

Wat de soort van ziekten en de vatbaarheid van ziek worden onder het personeel der active dienst op de lijnen van Lyon en Orleans betreft, zoo kwamen het veelvuldigst voor: $1^{0}$ ligte andoeningen der spijsverteringsorganen; $2^{0}$ ligte aandoeningen der ademhalingsorganen; $3^{0}$ gewrichts- en spierrhumatisme; $4^{0}$ aandoeningen der bersenen, en $5^{\circ}$ bnidziekten. Uitwendige ziekten en kwetsuren komen voor $\frac{1}{3}$ onder het geheele ziekte-cijfer voor.

Onder de stoker's en machinisten $k$ wamen het meest voor: ziekten der adembaling- en spijsverteringswerktuigen en enkele verwondingen. Overigens weinig aandoeningen welke op een directen invloed van het beroep wijzen.

Onder het overige personeel voor het vervoer kwamen genoegzaam dezelfde aandoeningen, doch in geringere mate en hevigheid voor. Menigvuldiger waren oogziekten; zeldzamer darentegen tusschenpoozende koortsen en beenbreuken. Bij hen werd overigens geene bepaalde ziekte waargenomen, met het beroep in verband te brengen.

$\mathrm{Bij}$ het personeel in de werkplaatsen en magazijnen kwamen meer ziekten voor dan bij de eerstgrenoemden; veel ziekten der spijsverteringsorganen, voorts verwondingen en oogontstekingen, veel gewrichtsrhumatisme, weinig huidziekten. De metaalkoliek bij de metaalwerkers en schilders duidde alleen op iets specifieks bij die soort van werklieden. Bij de grofsmeden $\mathrm{zag}$ men veel huidziekten, aderspatten en breuken. Bij de geringste soort van werklieden, (die ook het karigst worden bezoldigd), kwamen de meeste ziekten voor, vooral die der ademhalingsorganen.

De beambten voor den weg, wachters enz. waren het gezondst van allen $(*)$; koortsen en ademhalingsziekten nam men bij ben niet of zeer zelden war.

(*) Dergelijke bijzonderheden, vl. vergelijking van den gezondheidstoestand der verschillende soorten van beambten, rekenen wij hoogst leerzan, vooral als $z i j$ over eene reeks van jaren loopen. Wat de gunstige sterfteverhouding bij de be- 
Bij het personeel op de bureaux van administratie werkzaam, verschilde de aard en de menigvuldigheid der ziekten niet met die bij andere bureau beambten. Aandoeningen der hersenen stonden vooral bij hen op den voorgrond.

Uit dit algemeen overzigt blijkt alzoo, dat de spoorwegen cen gunstigen invloed op het daarbij werkzame personeel uitorfenen, en dat, met enkele uitzonderingen van de werklieden in metalen en de schilders, geen bijzondere ziekten bij ben voorkomen, welke uitshitend an hunue beroepen moeten toegeschreven worden.

Die verklaring door den Schrijver gedaan op gezag van de gencesheeren aan de onderscheidene lijnen verbonden, en door de uitkomsten der statistiek verkregen, wordt echter niet door alle geleerlen welke zich met dat onderzoek hebben bezig gehouden, gedeeld, en hoewel sommigen, zooals we boven zeiden, reeds van hunne dwaling terug zijn gekomen, houden anderen nog hardnekkig aan hunne beweringen vast, in weerwil dat de cijfers hun geheel het tegendeel aantoonen. De Schrijver beeft dan ook gemeend, om der onpartijdigheidswille, de gevoeleus van anderen in zijn geschrift kortelijk te moeten vermelden en de gronden uiteen te zetten die hij en zijue medestrijders tot staving bunner uitspraken aanvoeren.

Door de eersten zijn nanelijk aan de stokers en machinisten onderscheidene ziekten toegedicht, waaraan zij bijzonder onderhevig zouden $z i j n$, en wel: $1^{0}$ eene bijzondere zenuwachtige andoening, $2^{0}$ eene eigenaardige ziekte, de ziekte der machinisten genoend, $3^{0}$ rhumatische pijnen, $4^{0}$ tusschenpozende koortsen, $5^{0}$ gebrekeu in het geboor en $6^{0}$ gebreken in het gezigtsvermogen.

De Schrijver onderneemt nu, de waarde van elk dier beweringen te onderzoeken en bedient zich daarbij meestal vau de getuigenissen der geneesheeren aan de administratiën verbonden. Wiij zouden weder te onbescheiden zijn, indien wij van de Redactie de noodige ruimte zouden

ambten in 't algemeen tegenover die der geheele bevolking betreft, zoo valt het moeijelijk hieromtrent een juiste vergelijking te maken. Immers de spoorwegbeambten zullen in den regel wel uitgezochte gezoude menschen zijn, die goed loon trekken en goed gekleed en gevoed zijn. Dergelijke gedeelte der bevolking zal onvermijdelijk gunstiger cijfers moeten aantoonen dan de geheele berolking, al neent men de mannelijke volwassenen van soortgelijken leeftijd afzonderijk. Men zou dus te ver gaan indien men het gunstig verschil uitsluitend aau hec beroep wilde toeschrijuen. Dat echter bij dat uitgezochte personeel de beambten aan den weg het gezondste van allen waren, levert weer een sprekeud bewijs van het roordeel van zuivere lucht, dat goedkoope geneesmiddel dat ieder rerlurijgen kan, doeh bij den apotheker nijet te bekomen is.

RED. 
eischen, om al de bewijggronden hier mede te deelen, die de Schrijver op gezag van de geneesheeren der fransche spoorwegen hier anvoert. De strijd over de aangeduide ziekten wordt voornamelijk tegen den heer DUCHESNE gevoerd, en het gansche hoofdstuk bevat dan ook niets anders dan plaatsen uit het geschrift van Dockesne, waar tegenover de Schrijver weder andere zijner (Duchesnes) tegenpartij stelt. De gronden waarop Duchesne zijne beweringen vestigt, komen op de rolgende redenering neder: „De machinist," zegt hij, „heeft gedurende de reis aanhoudend zijn ligchaam en geest ingespannen; zijne oplettendheid is altijd waakzaam, zijne oogen zijn voortdurend gevestigd deels op den weg die afgelegd moet worden, deels op de machine die hij bestuurt; het oor steeds luisterend naar de verwijderde geluiden, vangt gedurig de schrille toonen der kleppen en van den stoom op. Altijd op de machine staande, is zijn ligchaam in eene gestadige en hevige beweging, en alleen door het balanceren kan bij het evenwigt bewaren en zich voor vallen hoeden; vóór zijne beenen opent zich gedurig het fornuis, welks gloeijende hitte hij gestadig opvangt; het overige van het ligchaam is aan de brandende zonnestralen, aan strenge koude, regen en wind blootgesteld!" Ziedaar zoovele momenten die à priori reeds eene ongunstige uitkomst ten opzigte van den gezondheidstoestand dier klasse van werklieden zonden kunnen doen vermoeden. Maar zoo als het zoo dikwijls gaat met aprioristische beschouwingen: zij worden in de praktijk veeltijds tegengesproken. En dat wordt hier door even practische als onbevooroordeelde mannen in let helderste licht gesteld, terwijl zij de onloochenbare cijfers te baat genomen hebben, om hunne beweringen te staven. Eene nadere enquête, in gevolge de opgesomde aandoeningen door DucBesser in het werk gesteld, heeft zelfs bewezen, dat de stokers en machinisten minder dan andere werklieden lie onder genoegzaam dezelfde omstandigheden werken, aan genoemde ziekten en gebreken lijden, en dat zij in rele opzigten tot de gezondsten van het geheele personeel der active dienst gebragt moeten worden. (*)

De Schrijuer wijdt vervolgens nog eene afzonderlijke $\$$ aan "de ongelukken der beambten." Hier zien wij het omgekeerde plaats hebben, als bij de statistiek der ongelukken onder de reizigers; bet anntal slagtoffers "door gebreken in de dienst" is hier minder dan bij de reizigers, terwijl het cijfer der "ongelukken door onvoorzigtigheid" daarentegen grooter is; eese uitkomst die trouwens voor de hand ligt.

(*) Wat den invloed op de gezondheid van machinisten en stokers betreft, zie men Ned. Tijdsch, van Geneesk. 1859 p, 458. Door Dr. H. v. C. te Amst. alsmede Economist, 1859. p. 334. v.

RED, 
Van 7 Sept. 1835 tot 31 Dec. 1854 zijn 158.399 .994 personen vervoerd en door 1869 ongelukken van allerlei aard, werden 1754 slagtoffers gemaakt en wel in de volgende verhouding:

door gebreken in de dienst $\left\{\begin{array}{lr}\text { reizigers } & 400 \\ \text { geëmployeerden } & 186 \\ \text { andere personen } & 11\end{array} \mid 597\right.$

Het aangeduide verschil wordt hier dus rrij zigtbaar aangetoond. De ongelukken van beiderlei aard nemen echter in verhouding tot de uitbreiding der spoorwegen, door de aangebragte verbeteringen in machineriën en reglementen, jaarijks af. Elke nieuw geëxploiteerde lijn moet echter haar contingent ongelukkeu leveren, deels door onvolkomenheden van den weg, deels door onervarenheid van het nieuw angestelde personeel veroorzaakt.

Tot besluit geeft de Schrijver onder het opschrift: „Hygiène der beambten" eene reeks van voorschriften welke zij in acht te nemen hebben, om hunne gezondheid te bewaren. Zij zijn allerbehartigenswaardig, doch verschillen weinig of niet van die welke men aan jeder ander mensch zou geven, die met vermoeijenden handenarbeid in zijne behoeften moet voorzien.

Een van de hoofdmomenten, dat bij de waardering van den gezondheidsstaat der geëinployeerden aan de spoorwegen en vooral bij het personeel der active dienst niet uit het oog mag verloren worden, is de bijzondere omzigtigbeid waarmede de directiën te werk gaan, in de keus der personen. Hij die eene betrekking an de spoorwegen verlangt, moet zoowel in zedelijke als ligchamelijke en verstandelijke ontwikkeling de beste getuigenissen kumen proluceren. Het spreekt van zelfs dat ten opzigte der beide laatste hoedanigheden onderscheiding gemaakt wordt nat den aard der aaugeboden diensten. Aan het personeel der active clienst worden echter de hoogste eischen gedaan. Het moeten goed gebouwde, gezonde en verstanilelijk goed ontwikkelde personen van middellıaren leeftijd ( $25-48$ jaar) zijn. De direktie zorgt van haren kant voor de gezondheid en veiligheid van haar dienstpersoneel door: goede loonen in verhouding der gepraesteerde diensten, geschikte verdeeling van den arbeid en van de uren van arbeid en rust; behoorlijke maatregelen in het belang der gezonden en zieken; streng, zedelijk toezigt; de invoering en handhaving van goede voorschriften in het belang der bijzondere en openbare peiligheid.

Lin un bomt ten slotie het oordeel van den Schrijuer over den 
invloed der spoorwegen op de gezondheid der beambten en reizigers op het volgende neder:

$1^{0}$ Bij den teyenwoordigen stand der wetenschap heeft de kwestie omtrent den invloed der spoorwegen op de gezondleid der reizigers nog tot geen voldoend en bepaald resultaat geleid; 2 De ongemakken door het verkeer op de spoornegen zijn gering en verminteren gaandeweg door ingevoerle verbeteringen; $3^{\circ}$ De gevaren voor de reizigers zijn, in verhouling van het verkeer met andere middelen van vervoer, veel geringer bij het vervoer door iniddel van spoorwegen; $4^{0}$ De invloed der spoorwegen op de gezondheid der beambiten is over het algemeen zeer gunstig; de opgesomde ziekten en gebreken eigen aan stokers en machinisten bestaan niet.

Volgaarne stemmen wij dan ook in met de phrase, waarmede hij zijn werkje besluit: „Ces heureux résultats ne peuvent qu'augmenter notre admiration pour les railways, ces propagateurs actifs et incessants de progrès et de civilisation."

En hiermede hebben wij de taak volbragt, die wij op ons hebben genomen. Wij hebben in den gang van ons verslag gepooud, de leemten en gebreken die den arbeid van PreTrs SANTa aankleeft, zooveel mogelijk aan te toonen. Welke arbeid heeft echter niet zijne zwakke zijden en verwonderen moge het ons niet, die vaak hier aan te treffen, daar de aard der onderzoekingen eene juiste constatering der feiten veeltijds oumogelijk maakte en hare waarde niet altijd in het juiste licht konde geplaatst worden.

Wat de Schrijuer echter heeft aangenomen en wilde bewijzen, stende op goede gronden. De getuigenissen van anderen en de cijfers in het boekje neergelegd, zijn ons daarvoor waarborgen genoeg geweest. Als zoodanig hopen ook wij met het stellen dezer regels geen nutteloos werk te hebben verrigt.

Dr. S. SR. C. 